\title{
Use of analogues of luteinizing hormone-releasing hormone for the treatment of cancer
}

\author{
B. J. A. Furr and R. I. Nicholson* \\ Bioscience I Department, Imperial Chemical Industries Limited, Pharmaceuticals Division, \\ Alderley Park, Macclesfield, Cheshire SK10 4TG and *Tenovus Institute for Cancer Research, \\ Welsh National School of Medicine, Cardiff CF4 4XX, U.K.
}

\section{Introduction}

When research on luteinizing hormone-releasing hormone (LH-RH) and analogues started in many pharmaceutical companies, it was predicted that these agents would be used for the treatment of hypogonadal states in human clinical medicine and for the regulation and improvement of fertility in veterinary medicine. The major objective, however, was to produce an antagonist of LH-RH which could be used primarily as an antifertility agent in men and women. Like a number of other biologically potent molecules the unexpected results provided by LH-RH and its agonistic analogues changed both the impetus and direction of research.

The finding that potent analogues of $\mathrm{LH}-\mathrm{RH}$ would prevent puberty when given continuously to immature female rats and would cause ovarian and uterine atrophy in mature rats (Johnson, Gendrich \& White, 1976; Vale, Rivier, Rivier \& Brown, 1977) prompted a rapid re-appraisal of the therapeutic potential of these agents. The paradoxical anti-gonadal effect was not confined to the female since potent analogues of LH-RH were shown to prevent sexual maturation in the male, to reduce the weights of the testes and accessory sex organs, and to arrest spermatogenesis and decrease plasma androgens (Oshima et al., 1975; Auclair, Kelly, Labrie, Coy \& Schally, 1977; Vale et al., 1977; Pelletier et al., 1978; Tcholakian et al., 1978; Rivier, Rivier \& Vale, 1979).

Although prevention of conception remains a very important potential use for potent LH-RH analogues, a number of problems will have to be overcome before such agents reach the stage of extensive clinical trial. In the shorter term exploitation of the castration-like effects produced by LH-RH analogues will be in the treatment of precocious puberty, endometriosis and benign and malignant diseases of the breast and prostate. Since clinical trials are now beginning with these agents in the treatment of hormone-responsive tumours, it is timely to describe data from tumour models in animals which support the belief that analogues of LH-RH may well prove clinically effective.

\section{Rat mammary tumours induced by dimethylbenzanthracene (DMBA)}

Huggins, Grand \& Brillantes (1961) showed that administration of DMBA to young female rats resulted in the formation of mammary tumours. This so-called DMBA-induced mammary tumour model has proved most valuable for the study of hormone-dependent cancer because it responds to a range of ablative and additive endocrine therapies that are effective in women with breast cancer. Ovariectomy (Huggins et al., 1961; Manni, Trujillo \& Pearson, 1977; Fiebig \& Schmahl, 1977), hypophysectomy (Daniel \& Pritchard, 1963), pharmacological doses of oestrogens (Pearson, Molina, Butler, Llerena \& Nasr, 1972), antioestrogens (Desombre \& 
Arbogast, 1974; Nicholson \& Golder, 1975; Jordan, 1976; Jordan \& Koerner, 1976; Manni et al., 1977), progesterone (Huggins et al., 1961) and cytotoxic agents (Fiebig \& Schmahl, 1977) all produce tumour regression. The observations of Danguy et al. (1977) and Desombre, Johnson \& White (1978) that D-Leu ${ }^{6}$, des Gly ${ }^{10}$, Pro-ethylamide'-LH-RH also caused marked regression of DMBA-induced mammary tumours prompted a number of studies with ICI 118630, D-Ser $\left(\mathrm{Bu}^{\mathrm{t}}\right)^{6}$, Azgly ${ }^{10}$ - $\mathrm{LH}-\mathrm{RH}$, an analogue approximately $50-100$ times as potent as the natural deca-peptide at inducing ovulation in constant-oestrous, androgen-sterilized rats (Dutta, Furr, Giles \& Valcaccia, 1978a).

In all studies the tumours were measured by calipers along the longest axis and the axis perpendicular to it. In an initial experiment (Dutta, Furr, Giles, Valcaccia \& Walpole, 1978b), 6 rats were given s.c. injections for 28 days, starting 104 days after administration of DMBA, of saline or ICI $118630(5 \mu \mathrm{g} / \mathrm{rat}$ twice daily on weekdays and $5 \mu \mathrm{g} / \mathrm{rat}$ daily on Saturdays and Sundays). Tumour numbers and area, calculated from the product of the two measurements, were recorded weekly. The results shown in Text-fig. 1 demonstrate a clear regression of tumours in animals treated with ICI 118630 compared with a marked increase in size in the controls. A complete disappearance of the tumour occurred in 5 cases and no new tumours were found in the treated group. In contrast 8 new tumours were palpated in the control group by the end of the 28-day dosing period (Table 1).

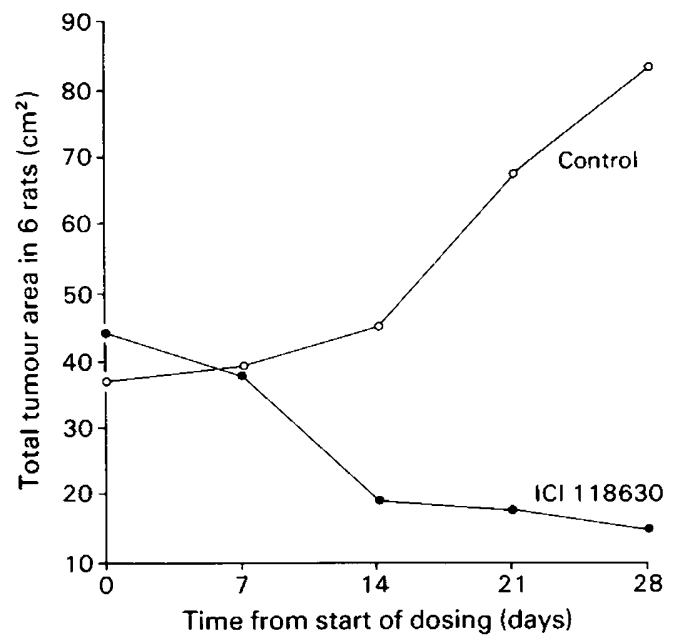

Text-fig. 1. Effect of subcutaneous treatment twice daily for 28 days with $5 \mu \mathrm{g}$ ICI 118630 on the total tumour area in 6 rats with DMBA-induced mammary tumours. Six rats given vehicle served as controls.

Table 1. Change in numbers of DMBA-induced mammary tumours in rats following subcutaneous treatment twice daily with $5 \mu \mathrm{g}$ ICI 118630

\begin{tabular}{ccc}
\hline \multirow{2}{*}{$\begin{array}{c}\text { Time after dosing } \\
\text { (days) }\end{array}$} & \multicolumn{2}{c}{ Number of measurable tumours } \\
\cline { 2 - 3 } & Control & 118630 treated \\
\hline 0 & 11 & 13 \\
7 & 12 & 13 \\
14 & 13 & 10 \\
21 & 16 & 8 \\
28 & 19 & 8 \\
\hline
\end{tabular}


A more detailed study was then performed (Nicholson \& Maynard, 1979). Five weeks after administration of DMBA, rats were palpated for tumours at weekly intervals and the tumour volume was calculated using the formula $(4 / 3) \pi r^{3}$, where $r$ is the mean radius. When tumours reached an appropriate size $\left(1.76 \mathrm{~cm}^{3} ; 1.5 \mathrm{~cm}\right.$ mean diameter) a small portion $(\sim 100 \mathrm{mg})$ was removed under ether anaesthesia and stored at $-20^{\circ} \mathrm{C}$ for oestrogen receptor analysis (Nicholson, Davies \& Griffiths, 1978). The animals were divided into 6 groups and treated for 20 days as follows.

Group I. Eleven animals bearing 18 tumours received twice daily i.m. injections of $5 \mu \mathrm{g}$ ICI 118630 in $0.1 \mathrm{ml}$ saline $(9 \mathrm{~g} \mathrm{NaCl} / \mathrm{l})$.

Group $I I$. Seven animals bearing 9 tumours received twice daily injections of $0.5 \mu \mathrm{g}$ ICI 118630 in $0.1 \mathrm{ml}$ saline.

Group III. Eight animals bearing 12 tumours received twice daily injections of $0.05 \mu \mathrm{g} \mathrm{ICI}$ 118630 in $0.1 \mathrm{ml}$ saline.

Group $I V$. Seven animals bearing 13 tumours received twice daily injections of $0.1 \mathrm{ml}$ saline.

Group $V$. Nine animals bearing 12 tumours were ovariectomized at the start of the dosing period and were then given twice daily injections of $0.1 \mathrm{ml}$ saline.

Group VI. Nine animals bearing 12 tumours received daily i.m. injections of $100 \mu \mathrm{g}$ of the antioestrogen, tamoxifen; in $0.1 \mathrm{ml}$ sesame oil.

After completion of the treatment period regrowth of the tumours was monitored at weekly intervals and animals in Groups I-III and VI were ovariectomized when at least one tumour in each animal reached a tumour volume of more than $8.2 \mathrm{~cm}^{3}(2.5 \mathrm{~cm}$ mean diameter $)$.

Blood samples were obtained from the tumour bearing animals at the end of the treatment period and plasma oestradiol was estimated by radioimmunoassay (Maynard \& Nicholson, 1979).
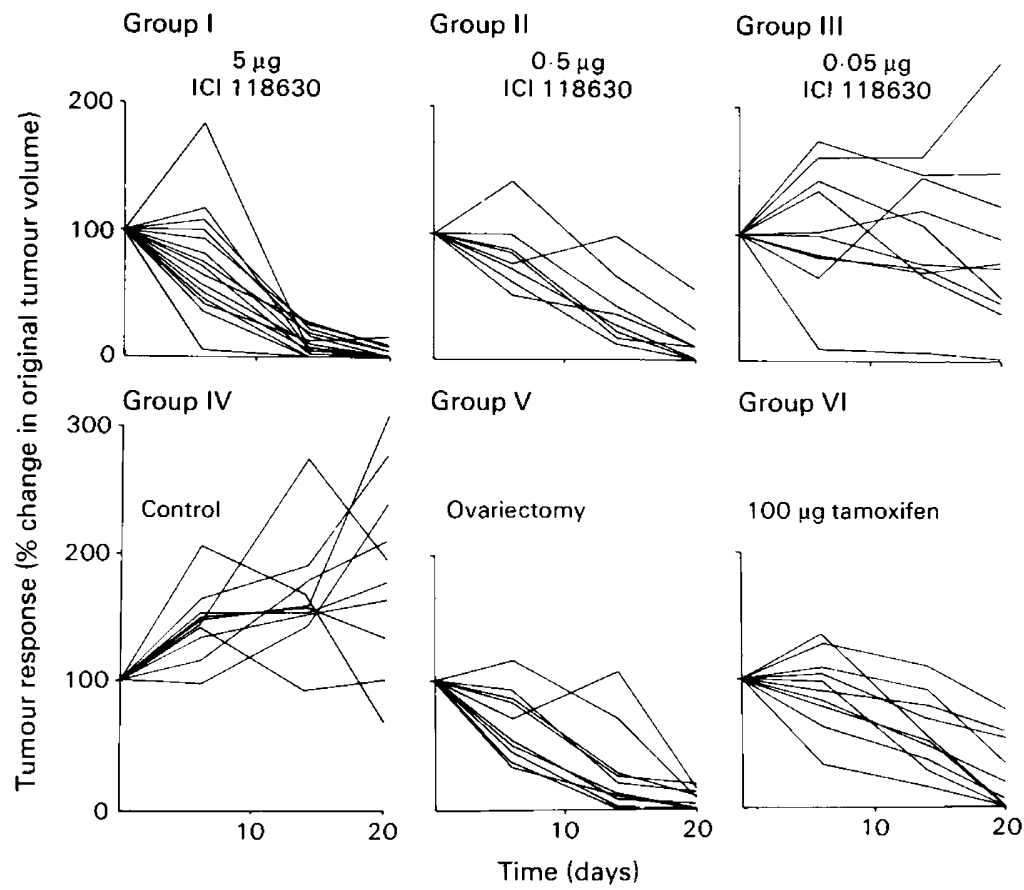

Group VI

$100 \mu \mathrm{g}$ tamoxifen

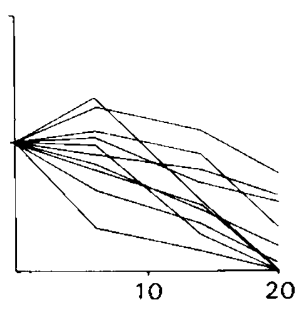

Text-fig. 2. Response of oestrogen receptor-positive DMBA-induced rat mammary tumours to treatment with ICI 118630 and tamoxifen. Groups I to III were injected twice daily for 20 days with the doses of ICI 118630 shown; Groups IV and V received $0.9 \%(\mathrm{w} / \mathrm{v})$ saline and Group V was ovariectomized at the start of the treatment period. Group VI was given $100 \mu \mathrm{g}$ tamoxifen daily. 


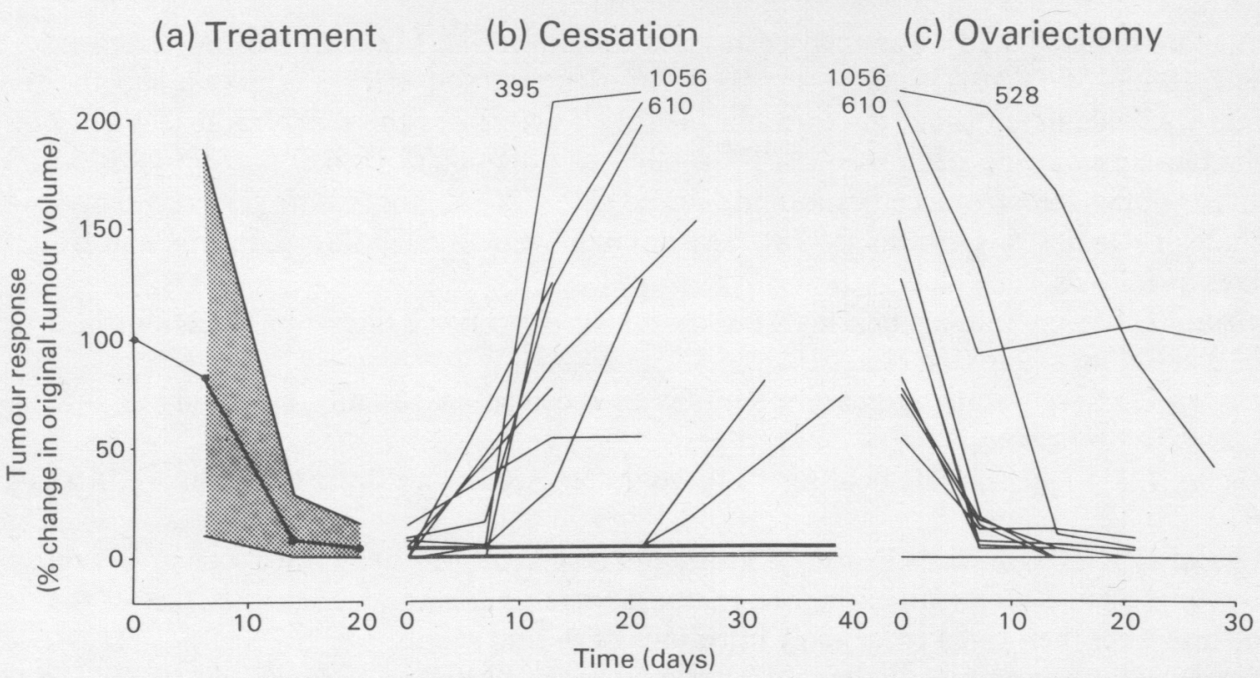

Text-fig. 3. Growth patterns of DMBA-induced rat mammary tumours during and after cessation of treatment with ICI 118630. (a) Ten animals with oestrogen receptor-positive tumours given $5 \mu \mathrm{g}$ ICI 118630 twice daily for 20 days. The points are the mean values and the range is shown by the stippled area. (b) Tumour regrowth after the cessation of treatment. (c) Further responses to ovariectomy.

All tumours assessed in the study were classified according to their oestrogen receptor (ER) content. Oestrogen receptor-positive tumours were defined as those containing more than 8 fmol ER/mg cytosol protein. Using this classification $78 \%$ of tumours were oestrogen receptor positive. Data on the effect of treatment on these tumours are shown in Text-figs 2 and 3. Doses of 5 and $0.5 \mu \mathrm{g}$ ICI 118630 were as effective as ovariectomy and $100 \mu \mathrm{g}$ tamoxifen in causing tumour regression over the 20-day treatment period. Reducing the dose of ICI 118630 to 0.05 $\mu \mathrm{g}$ markedly decreased its effectiveness.

After the end of treatment no further growth was seen in 5 tumours in animals treated with 5 $\mu \mathrm{g}$ ICI 118630 . Of the remaining 10 tumours, 2 showed a most marked increase in volume during the 20-day period following treatment (Text-fig. 3). Tumours which regrew after treatment with ICI 118630 retained hormone dependency and regressed again after ovariectomy (Text-fig. 3).

The growth patterns of 7 oestrogen receptor-negative tumours in animals treated with ICI 118630 or tamoxifen are shown in Text-fig 4. Five tumours continued to grow but 2 tumours in animals treated with ICI 118630 regressed. In the three instances when ovariectomy was performed after the cessation of treatment, a progressive tumour growth pattern was maintained (Text-fig. 4). During the study, 2 fibroadenomas were detected; both were unresponsive to ICI 118630 treatment and ovariectomy.

In addition to the effects observed on tumour growth, ICI 118630 also decreased the number of new tumours appearing during treatment (Table 2). The effect was clear even at the lowest dose level of $0.05 \mu \mathrm{g}$ ICI 118630 . When treatment ceased, some growth of new tumours did occur, although the total number of tumours found was less than in the control group. The growth patterns of the newly formed tumours after cessation of treatment are shown in Text-fig. 5. Of the 11 tumours examined, 9 were detected within 21 days of drug withdrawal. Where ovariectomy was performed, it was shown that all 7 tumours were hormone-dependent (Text-fig. 5). Similar results were observed in the group treated with tamoxifen.

Twice daily treatment with $5 \mu \mathrm{g}$ ICI 118630 for 20 days significantly $(P<0.001)$ reduced plasma oestradiol concentrations to values indistinguishable from those of ovariectomized 
(a)

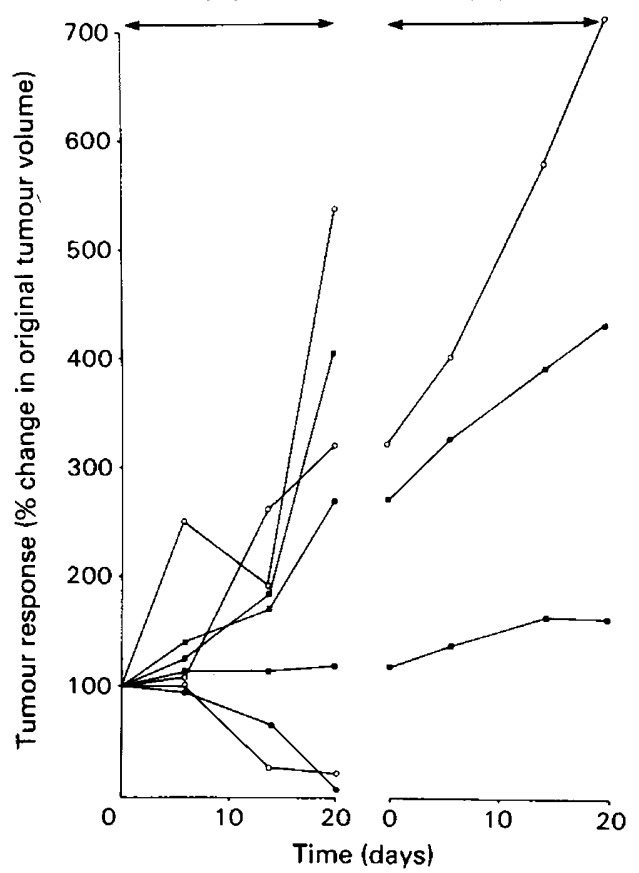

Text-fig. 4. Response of oestrogen receptor-negative, DMBA-induced mammary tumours to treatment with ICI 118630 and tamoxifen. (a) Animals injected twice daily for 20 days with $5 \mu \mathrm{g}$ ICI $118630(O)$, or $0.5 \mu \mathrm{g}$ ICI 118630 (O) or daily with $100 \mu \mathrm{g}$ tamoxifen (G). (b) Effect of ovariectomy on growth response in 3 animals.

Table 2. Effect of ICI 118630 , tamoxifen and ovariectomy on the development of DMBA-induced mammary tumours in rats

\begin{tabular}{|c|c|c|c|c|c|c|}
\hline \multirow{2}{*}{\multicolumn{2}{|c|}{ Group }} & \multirow[b]{2}{*}{$\begin{array}{l}\text { Dose/injection } \\
(\mu \mathrm{g})\end{array}$} & \multirow[b]{2}{*}{$\begin{array}{l}\text { No. of } \\
\text { animals }\end{array}$} & \multicolumn{2}{|c|}{ New tumours formed } & \multirow[b]{2}{*}{ Total } \\
\hline & & & & $\begin{array}{c}\text { During } \\
\text { treatment }\end{array}$ & $\begin{array}{c}\text { After } \\
\text { treatment }\end{array}$ & \\
\hline I & ICI 118630 & $5 \cdot 0$ & 11 & 0 & 8 & 8 \\
\hline & ICI 118630 & 0.5 & 7 & 0 & 3 & 3 \\
\hline III & ICI 118630 & 0.05 & 8 & 4 & 4 & 8 \\
\hline IV & Control & - & 7 & 16 & 2 & 18 \\
\hline V & Ovariectomy & - & 9 & 2 & 1 & 3 \\
\hline VI & Tamoxifen & 100 & 9 & 3 & 4 & 7 \\
\hline
\end{tabular}

animals (Table 3) and caused the appearance of a persistent pattern of dioestrous vaginal smears (Nicholson, Walker \& Maynard, 1980).

\section{'Adjuvant' therapy of DMBA-induced mammary tumours}

Clinical studies are currently underway with the antioestrogen, tamoxifen, and cytotoxic agents, given both alone and in combination, immediately after mastectomy. The hope is that such treatment, termed 'adjuvant' therapy, may increase the interval to recurrence of the disease and prolong survival time. Jordan (1978) has described a dosing regimen in the DMBA-induced tumour model which approximates to adjuvant therapy. In his model the drug is given, 


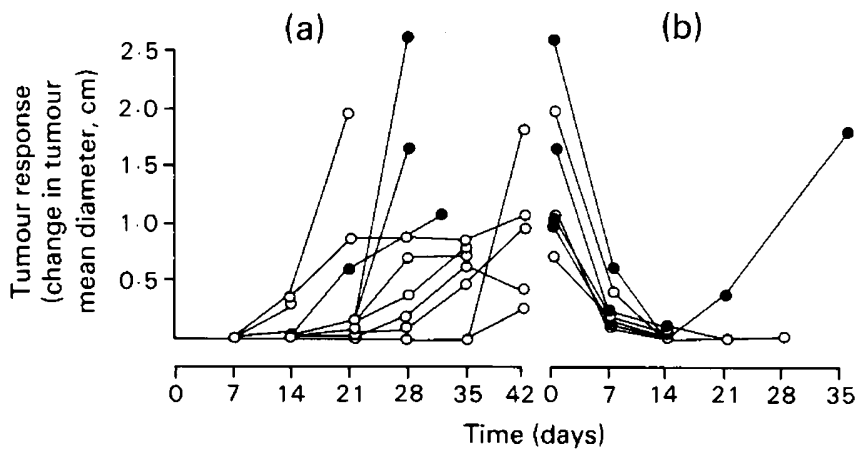

Text-fig. 5. Development of new tumours in rats after withdrawal ICI 118630. (a) Growth patterns of new tumours at the end of treatment with $5 \mu \mathrm{g}(\mathrm{O})$ or $0.5 \mu \mathrm{g}(\mathrm{O}) \mathrm{ICI} 118630$. (b) Response of tumours to ovariectomy.

Table 3. Effect of twice daily injections of $5 \mu \mathrm{g}$ ICI 118630 for 20 days and ovariectomy on plasma oestradiol $-17 \beta$ concentrations

\begin{tabular}{lc}
\hline Treatment & Plasma oestradiol conc. $(\mathrm{pg} / \mathrm{ml})^{*}$ \\
\hline Control & $33 \cdot 6(12 \cdot 4-60 \cdot 7)$ \\
ICI 118630 & $8 \cdot 6(3 \cdot 4-15 \cdot 0)$ \\
Ovariectomy & $8.7(3 \cdot 5-24 \cdot 0)$ \\
\hline
\end{tabular}

* Values are means, with ranges in parentheses, for 6 animals/group.

continuously or for a limited period, starting 30 days after tumour induction with the carcinogen, at a time when no tumours are palpable. Jordan (1978) has shown that in this situation tamoxifen is more effective than ovariectomy in inhibiting tumour development.

Thirty days after DMBA administration, treatment with ICI 118630 was initiated on a continuous basis in 20 rats with 40 animals serving as controls. The rats were palpated for tumours at weekly intervals and tumour sizes were recorded. Table 4 shows that the incidence of tumours was significantly reduced in animals treated with ICI 118630 (B. J. A. Furr, B. Valcaccia, C. Neal \& F. G. Hutchinson, unpublished results).

Table 4. Effect of ICI 118630 on the appearance of DMBAinduced mammary tumours in rats

\begin{tabular}{lcccc}
\hline & & \multicolumn{3}{c}{ Percentage of rats with tumours } \\
\cline { 3 - 5 } Treatment & $\begin{array}{c}\text { No. of } \\
\text { rats }\end{array}$ & 28 days & 42 days & 70 days \\
\hline Control & 40 & 17.5 & $55 \cdot 0$ & 92.5 \\
ICI $118630^{*}$ & 20 & 0 & 0 & 15.0 \\
\hline
\end{tabular}

* Given continuously for 90 days, 30 days after the induction of tumours with DMBA.

\section{Mechanism of action of ICI 118630 in causing tumour regression}

Tumour regression induced by ICI 118630 could be due to a direct effect of the drug on the tumour, or to indirect effects through an action on the pituitary gland or ovary.

Frequent administration of pharmacological doses of LH-RH analogues causes refractoriness of the pituitary gland of rats (Sandow, Von Rechenberg, Jerzabek \& Stoll, 1978), 


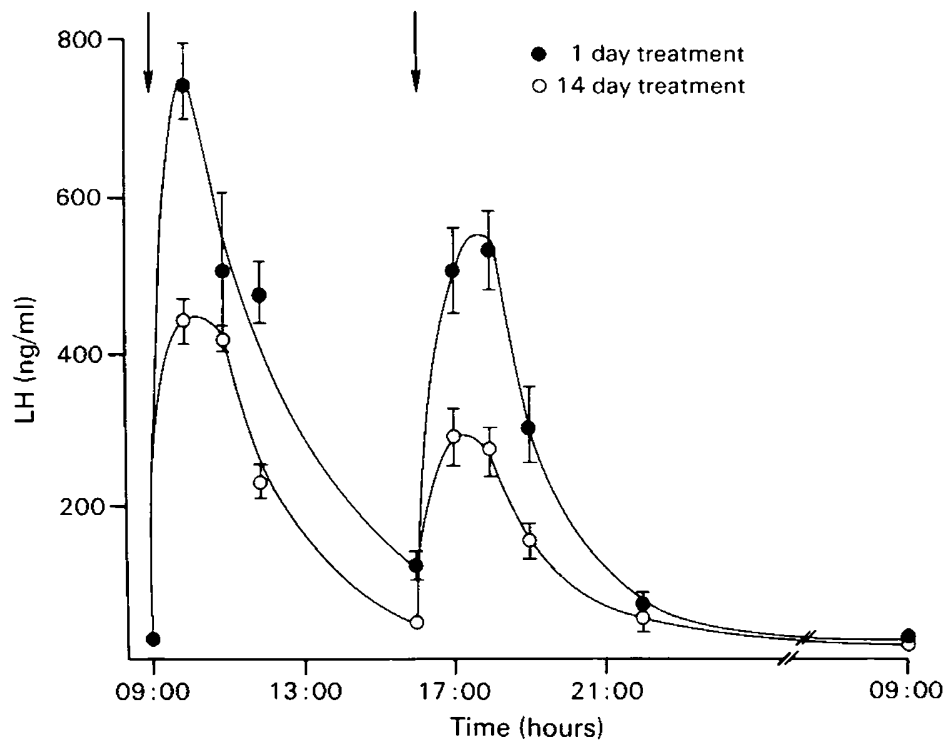

Text-fig. 6. Effect of ICI 118630 on plasma LH concentrations. Rats were given ICI 118630 twice daily for 1 day $(O)$ or 14 days $(O)$ and killed by exsanguination at the times indicated. The arrows show the times of injection. Plasma LH values are the mean \pm s.e.m. for 5 animals.

primates (Belchetz, Plant, Nakai, Keogh \& Knobil, 1978) and man (Berquist, Nillius \& Wide, 1979), and consequently prevents gonadal stimulation. However, the dosing regimen used in the dose-response study described here did not prevent $\mathrm{LH}$ release in the rat (Maynard \& Nicholson, 1979). Text-figure 6 shows that, although reduced, sustained LH release still occurred in response to ICI 118630 after 14 days treatment; at this time tumour regression was clearly observed. It therefore seems unlikely that down-regulation of pituitary LH-RH receptors accounts for the antitumour activity. Alternatively, it is possible that the gonadotrophin released in response to ICI 118630 causes down-regulation of ovarian LH receptors which accounts for the observed reduction in plasma oestradiol-17 $\beta$. There is certainly ample evidence that there is a marked loss of $\mathrm{LH}$ receptors and the steroidogenic response to gonadotrophin stimulation after systemic administration of LH and hCG (Hsueh, Dufau \& Catt, 1976, 1977; Sharpe, 1976; Auclair et al., 1977). Moreover, a similar down-regulation of gonadal LH receptors is observed after administration of LH-RH analogues (Auclair et al., 1977; Conti, Harwood, Dufau \& Catt, 1977; Kledzik, Cusan, Auclair, Kelly \& Labrie, 1978; Catt, Bakaul, Davies \& Dufau, 1979).

Table 5. The effects of hCG and ICI 118630 on ovarian and uterine weights and plasma oestradiol concentrations in groups of 6 hypophysectomized rats

\begin{tabular}{|c|c|c|c|}
\hline \multirow[b]{2}{*}{ Treatment } & \multicolumn{2}{|c|}{ Organ weight (mg/100 g body weight) } & \multirow{2}{*}{$\begin{array}{l}\text { Plasma oestradiol } \\
(\mathrm{pg} / \mathrm{ml})\end{array}$} \\
\hline & Ovaries & Uteri & \\
\hline Vehicle & $35 \cdot 8(32-39)^{* *}$ & $55.4(50-57)^{* *}$ & $20 \cdot 2(8 \cdot 5-50 \cdot 5)^{*}$ \\
\hline hCG & $71.9(45-113) \ddagger$ & $152.0(132-177) \ddagger$ & $50 \cdot 1(35 \cdot 2-61 \cdot 2) \dagger$ \\
\hline hCG + ICI 118630 & $39 \cdot 3(28-52)^{*}$ & $61.7(45-90)^{* \dagger}$ & $37 \cdot 3(21 \cdot 3-47 \cdot 2)^{*}$ \\
\hline ICI 118630 & $40 \cdot 5(31-45)^{*}$ & $58 \cdot 8(40-90)^{* *}$ & $29 \cdot 2(16 \cdot 9-34 \cdot 4)^{* *}$ \\
\hline
\end{tabular}

Animals were treated twice daily for 3 days and once daily on Day 4 with vehicle, hCG ( 25 i.u./injection), ICI $118630(5 \mu \mathrm{g} /$ injection $)$ or a combination of hCG (25 i.u./injection) and ICI $118630(5 \mu \mathrm{g} /$ injection). Animals were exsanguinated $1 \mathrm{~h}$ after the final injection on Day 4. The mean values are given and the range is shown in parentheses.

Significantly different from hCG-treated animals: ${ }^{*} P<0.05,{ }^{* *} P<0.005$ (Student's $t$ test).

Significantly different from vehicle-treated animals: $\dagger P<0.05 ; \ddagger P<0.005$ (Student's $t$ test). 
Once again, however, it is unlikely that this represents the complete mechanism of ICI 118630 action since the concurrent administration of the drug with hCG to hypophysectomized rats completely abolishes the hCG-stimulated increases in ovarian and uterine weights (Table 5) and reduces circulating concentrations of oestradiol (K. J. Walker \& R. I. Nicholson, unpublished). These events were observed in animals having no significant response to previously administered LH-RH and indicate a direct inhibitory action of ICI 118630 on the ovary with a subsequent reduction in circulating oestrogens. Such a concept is consistent with the findings of other workers using another synthetic LH-RH agonist, D-Leu ${ }^{6}$, des Gly ${ }^{10}$, Pro-ethylamide ${ }^{9}$-LH-RH (Rippel \& Johnson, 1976), and is reinforced by the recent observations of LH-RH binding proteins in ovarian tissue (Clayton, Harwood \& Catt, 1979; Reeves, Seguin, Lefebvre, Kelly \& Labrie, 1980). Furthermore, Hsueh \& Erikson (1979) and Hillier, Reichert \& van Hall (1981) have shown that LH-RH analogues, including ICI 118630, will inhibit steroidogenesis by granulosa cells in vitro in response to gonadotrophin. Similarly, ICI 118630 reduces ovarian aromatase activity in intact rats (K. J. Walker \& R. I. Nicholson, unpublished data).

Since DMBA-induced mammary tumours are responsive to prolactin (Sterental, Dominguez, Weissman \& Pearson, 1963; Pearson, Llerena, Llerena, Molina \& Butler, 1969; Bradley, Kledzik \& Meites, 1976; Manni et al., 1977), Danguy et al. (1977) concluded that the marked reduction in plasma prolactin found after treatment with $\mathrm{D}$-Leu ${ }^{6}$, des $\mathrm{Gly}^{10}$, Proethylamide - LH-RH was the primary cause of tumour regression. A reduction in plasma prolactin was also caused by ICI 118630 treatment (K. J. Walker, R. I. Nicholson \& B. J. A. Furr, unpublished data), as can be seen in Table 6 . This was probably a consequence of the reduction in plasma oestradiol, because oestrogens regulate prolactin release in the rat (Meites, 1972; Jordan \& Koerner, 1976). The interaction of oestrogen and prolactin in controlling growth of DMBA-induced tumours is worthy of further study before firm conclusions can be drawn about the relative importance of oestrogen and prolactin withdrawal on tumour growth.

Table 6. Effect of ICI 118630 on plasma prolactin concentrations in female rats

\begin{tabular}{lc}
\hline \multicolumn{1}{c}{ Time } & $\begin{array}{c}\text { Plasma prolactin } \\
\text { (ng NIH rat prolactin RP-1/ml) }\end{array}$ \\
\hline Pre-treatment & $43 \cdot 2 \pm 9 \cdot 6$ \\
After 5 days treatment & $19.7 \pm 8 \cdot 6$ \\
After 10 days treatment & $11.4 \pm 2.9^{* *}$ \\
After 21 days treatment & $10.2 \pm 2 \cdot 4^{* *}$ \\
1 day post-treatment & $39.5 \pm 13 \cdot 3$ \\
2 days post-treatment & $56 \cdot 0 \pm 23 \cdot 3$ \\
3 days post-treatment & $93.1 \pm 30.7$ \\
\hline
\end{tabular}

Groups of 6 rats were given $5 \mu \mathrm{g}$ ICI 118630 twice daily for 21 days. The rats were killed by exsanguination and the plasma prolactin concentrations were measured by radioimmunoassay. The values given are the means \pm s.e.m.

${ }^{* *} P<0.01$ compared with pre-treatment value; Student's $t$ test.

Recent observations, on castrated and hypophysectomized rats, that LH-RH and D-Trp ${ }^{6}$-des Gly $^{10}$, Pro-ethylamide ${ }^{9}$-LH-RH interfere with oestrogen and androgen action on the uterus and seminal vesicles respectively (Sundaram et al., 1981), suggest that a direct action of the drug on the tumour is a possibility. However, we have been unable to alter the response to testosterone propionate in castrated immature rats with ICI 118630 or D-Trp ${ }^{6}$-des Gly ${ }^{10}$, Pro-ethylamide9LH-RH (Table 7). Similarly neither analogue of LH-RH had an effect on uterine weight increases caused by oestradiol (Table 8). The reasons for the discrepancies between these results and those of Sundaram et al. (1981) are unclear. The principal difference between the studies 
was that Sundaram et al. (1981) used hypophysectomized rats, although it is difficult, in our studies, to envisage a pituitary factor released by these analogues which would effectively prevent their direct inhibition of steroid action. Furthermore, in rats bearing DMBA-induced tumours the pituitary gland was present, making it unlikely that this mechanism is relevant to the antitumour properties of ICI 118630 . In support of this conclusion are the findings of J. Yates \& R. B. King (personal communication) that ICI 118630 has no effect on growth of the androgen-responsive, Shionogi mammary tumour line in vitro, both in the presence and absence of testosterone.

Table 7. Effect of D-Trp ${ }^{6}$, des Gly ${ }^{10}$, Pro-ethylamide - LH-RH and ICI 118630 on ventral prostate weights in castrated immature rats given testosterone propionate $(200 \mu \mathrm{g} / \mathrm{kg})$ daily for 7 days

\begin{tabular}{|c|c|c|c|}
\hline \multicolumn{2}{|l|}{ Experiment A } & \multicolumn{2}{|c|}{ Experiment B } \\
\hline Treatment & $\begin{array}{l}\text { Wt of prostate gland } \\
(\mathrm{mg} / 100 \mathrm{~g} \text { body wt })\end{array}$ & Treatment & $\begin{array}{l}\text { Wt of prostate gland } \\
\text { (mg/100 } \mathrm{g} \text { body } \mathrm{wt})\end{array}$ \\
\hline $\begin{array}{l}\text { Control } \\
\text { D-Trp }{ }^{6} \text { des Gly }{ }^{10}, \text { Pro-ethylamide }{ }^{9}-\text { LH-RH } \\
\left(10 \mu \mathrm{g} / \mathrm{rat}^{2} \sim 100 \mu \mathrm{g} / \mathrm{kg}\right) \\
\text { D-Trp } \\
\quad(50 \mu \mathrm{g} / \mathrm{rat} ; \sim 500 \mu \mathrm{g} / \mathrm{kg})\end{array}$ & $\begin{array}{l}37 \cdot 8 \pm 2 \cdot 8 \\
41 \cdot 8 \pm 2 \cdot 0 \\
37 \cdot 3 \pm 2 \cdot 3\end{array}$ & $\begin{array}{l}\text { Control } \\
\text { Flutamide }(2 \mathrm{mg} / \mathrm{kg}) \\
\text { ICI } 118630(20 \mu \mathrm{g} / \mathrm{kg}) \\
\text { ICI } 118630(100 \mu \mathrm{g} / \mathrm{kg}) \\
\text { ICI } 118630(500 \mu \mathrm{g} / \mathrm{kg})\end{array}$ & $\begin{array}{l}37 \cdot 1 \pm 1 \cdot 7 \\
22.9 \pm 1 \cdot 1^{* * *} \\
39.8 \pm 2 \cdot 8 \\
37.8 \pm 2 \cdot 6 \\
38.1 \pm 3 \cdot 8\end{array}$ \\
\hline
\end{tabular}

All rats were killed on Day 8. Values are mean \pm s.e.m. for 5 rats/group. ${ }^{*} P<0.001$ compared with control (Student's $t$ test).

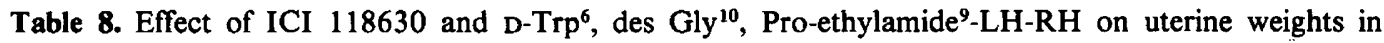
21-day-old female rats given 3 daily subcutaneous injections of $0.5 \mu \mathrm{g}$ oestradiol benzoate alone or in combination with the LH-RH analogue; ail rats were killed on Day 4

\begin{tabular}{|c|c|c|c|}
\hline \multicolumn{2}{|l|}{ Experiment A } & \multicolumn{2}{|l|}{ Experiment B } \\
\hline Treatment & $\begin{array}{l}\text { Uterine wt } \\
(\mathrm{mg} / 100 \mathrm{~g} \\
\text { body wt) }\end{array}$ & Treatment & $\begin{array}{l}\text { Uterine wt } \\
\text { (mg/100g } \\
\text { body wt) }\end{array}$ \\
\hline Untreated control & $53 \cdot 0 \pm 4 \cdot 0$ & Untreated control & $44.9 \pm 1.6$ \\
\hline $\begin{array}{l}\text { Oestradiol benzoate } \\
\text { Oestradiol benzoate + ICI } 118630\end{array}$ & $\begin{array}{l}234 \cdot 6 \pm 12 \cdot 1 \\
241 \cdot 1 \pm 7 \cdot 6\end{array}$ & $\begin{array}{l}\text { Oestradiol benzoate } \\
\text { Oestradiol benzoate }+\end{array}$ & $\begin{array}{l}240 \cdot 4 \pm 5 \cdot 5 \\
243 \cdot 8 \pm 10 \cdot 2\end{array}$ \\
\hline$(10 \mu \mathrm{g} / \mathrm{rat})$ & & $\begin{array}{l}\text { D-Trp }{ }^{6} \text {, des Gly }{ }^{10}, \text { Pro-ethylamide9- } \\
\text { LH-RH }(10 \mu \mathrm{g} / \mathrm{rat})\end{array}$ & \\
\hline $\begin{array}{l}\text { Oestradiol benzoate + ICI } 118630 \\
\quad(100 \mu \mathrm{g} / \text { rat })\end{array}$ & $246 \cdot 1 \pm 8 \cdot 6$ & $\begin{array}{l}\text { Oestradiol benzoate }+ \\
\text { D-Trp }^{6} \text {, des Gly }{ }^{10}, \text { Pro-ethylamide } \\
\text { LH-RH }(100 \mu \mathrm{g} / \text { rat })\end{array}$ & $248.9 \pm 6 \cdot 8$ \\
\hline
\end{tabular}

Values are mean \pm s.e.m. for 5 rats/group. The analogue doses of 10 and $100 \mu \mathrm{g} / \mathrm{rat}$ were equivalent to $\sim 200$ and $\sim 2000 \mu \mathrm{g} / \mathrm{kg}$.

It is concluded that withdrawal of oestrogen and prolactin in the DMBA-induced tumour model leads to tumour regression. This is caused initially either by a direct effect of the drug at the ovary, or by down-regulation of ovarian $\mathrm{LH}$ receptors induced by release of endogenous $\mathrm{LH}$ in response to the drug. Although there is no evidence that prolactin influences growth of breast tumours in man, oestrogens have been implicated in this respect. Thus treatment of pre-and peri-menopausal women with analogues of LH-RH may offer an alternative to oophorectomy as a therapy for advanced breast cancer and also as an adjuvant to surgery at mastectomy.

We wish to thank the Tenovus Organisation for financial support; Professor L. E. Reichert for highly purified ovine LH; N.I.A.M.D.D. for radioimmunoassay kits for FSH, LH and prolactin; L. Hardman and B. Valcaccia for skilled technical assistance; and K. J. Walker whose work forms part of a Ph.D. thesis. 


\section{References}

Auclair, C., Kelly, P.A., Labrie, F., Coy, D.H. \& Schally, A.V. (1977) Inhibition of testicular luteinizing hormone receptor level by treatment with a potent luteinizing hormone-releasing hormone agonist or human chorionic gonadotrophin. Biochem. biophys. Res. Commun. 76, 855-862.

Belchetz, P.E., Plant, T.M., Nakai, Y., Keogh, E.J. \& Knobil, E. (1978) Hypophyseal responses to continuous and intermittent delivery of hypothalamic gonadotrophin-releasing hormone. Science, N.Y. 202, 631-633.

Berquist, C., Nillius, S.J. \& Wide, L. (1979) Reduced gonadotrophin in postmenopausal women during treatment with a stimulatory LRH analogue. J. clin. Endocr. Metab. 49, 472-474.

Bradley, C.J., Kledzik, G.S. \& Meites, J. (1976) Prolactin and estrogen dependency of rat mammary cancers at early and late stages of development. Cancer Res. 36, 319-324.

Catt, K.J., Bakaul, A.J., Davies, T.F. \& Dufau, M.L. (1979) Luteinizing hormone-releasing hormoneinduced regulation of gonadotropin and prolactin receptors in the rat testes. Endocrinology 104, 17-25.

Clayton, R.N., Harwood, J.P. \& Catt, K.J. (1979) Gonadotrophin-releasing hormone analogue binds to luteal cells and inhibits progesterone production. Nature, Lond. 282, 90-92.

Conti, M., Harwood, J.P., Dufau, M.L. \& Catt, K.J. (1977) Regulation of luteinizing hormone receptors and adenylate cyclase activity by gonadotrophin in the rat ovary. Molec. Pharmac. 13, 1024-1032.

Danguy, A., Negros, N., Heuson-Stiennon, J.A., Pasteels, J.L., Atassi, G. \& Heuson, J.C. (1977) Effects of a gonadotropin-releasing hormone (Gn-RH) analogue (A-43818) on 7,12,dimethylbenz(a)anthracene-induced rat mammary tumours. Histological and endocrine studies. Eur. J. Cancer 13, 1089-1094.

Daniel, P.M. \& Pritchard, M.L. (1963) The response of experimentally induced tumours in rats to hypophysectomy and to pituitary stalk section. Br.J. Cancer $15,446-453$.

Desombre, E.R. \& Arbogast, L.Y. (1974) Effect of the antioestrogen $\mathrm{CI}-628$ on the growth of rat mammary tumours. Cancer Res. 34, 1971-1976.

Desombre, E.R., Johnson, E.S. \& White, W.F. (1978) Regression of rat mammary tumours effected by a gonadoliberin analog. Cancer Res. 36, 3830-3833.

Dutta, A.S., Furr, B.J.A., Giles, M.B. \& Valcaccia, B. (1978a) Synthesis and biological activity of highly active $\alpha$-aza-analogues of luliberin. J. med. Chem. 21, 1018-1024.

Dutta, A.S., Furr, B.J.A., Giles, M.B., Valcaccia, B. \& Walpole, A.L. (1978b) Potent agonist and antagonist analogues of luliberin containing an azaglycine residue in position 10 . Biochem. biophys. Res. Commun. 81, 382-390.

Fiebig, H.H. \& Schmahl, D. (1977) The effect of ovariectomy, tamoxifen and the combination adriamycin and 5-FU on 7,12-dimethylbenz(a)anthracene-induced mammary cancer in the rat. Oncology 34, 58-61.

Hillier, S.G., Reichert, L.E. \& van Hall, E.V. (1981) Modulation of FSH-controlled steroidogenesis in rat granulosa cells: direct in-vitro effects of LHRH and ICI 118630. Molec. cell. Endocr. 23, 193-205.

Hsueh, A.J.W. \& Erikson, G.F. (1979) Extrapituitary action of gonadotropin-releasing hormone: direct inhibition of ovarian steroidogenesis. Science, N.Y. 204, 854-855.

Hsueh, A.J.W., Dufau, M.L. \& Catt, K.J. (1976) Regulation of luteinizing hormone receptors in testicular interstitial cells by gonadotropin. Biochem. Biophys. Res. Commun. 72, 1145-1152.

Hsueh, A.J.W., Dufau, M.L. \& Catt, K.J. (1977) Gonadotropin-induced regulation of luteinizing hormone receptors desensitization of testicular $3^{\prime}, 5^{\prime}$ cyclic AMP and testosterone responses. Proc. natn. Acad. Sci., U.S.A. 74, 592-595.

Huggins, C., Grand, L.C. \& Brillantes, P. (1961) Mammary cancer induced by a single feeding of polynuclear hydrocarbons and its suppression. Nature, Lond. 198, 204-207.

Johnson, E.S., Gendrich, R.L. \& White, W.F. (1976) Delay of puberty and inhibition of reproductive processes in the rat by a gonadotrophin-releasing hormone agonist analog. Fert. Steril. 27, 853-860.

Jordan, V.C. (1976) Effect of tamoxifen (ICI 46,474) on initiation and growth of DMBA-induced rat mammary carcinoma. Eur. J. Cancer 12, 419424.

Jordan, V.C. (1978) Use of the DMBA-induced mammary carcinoma system for the evaluation of tamoxifen treatment as a potential adjuvant therapy. In Reviews on Endocrine-Related Cancer, Suppl. pp. 49-55. ICI Ltd, Macclesfield.

Jordan, V.C. \& Koerner, S. (1976) Tamoxifen as an antitumour agent: role of oestradiol and prolactin. $J$. Endocr. 68, 305-311.

Kledzik, G.S., Cusan, L., Auclair, C., Kelly, P.A. \& Labrie, F. (1978) Inhibition of ovarian luteinizing hormone ( $\mathrm{LH})$ and follicle-stimulating hormone receptor levels with an LH-releasing hormone agonist during the estrous cycle in the rat. Fert. Steril. 30, 348-353.

Manni, A., Trujillo, J.E. \& Pearson, O.H. (1977) Predominant role of prolactin in stimulating the growth of 7,12-dimethylbenz(a) anthracene-induced mammary tumour. Cancer Res. 37, 1216-1219.

Maynard, P.V. \& Nicholson, R.I. (1979) Biological effects of high dose levels of a series of new LH-RH analogues in intact female rats. Br. J. Cancer 39, 274-279.

Meites, J. (1972) Relation of prolactin and estrogen to mammary tumorigenesis in the rat. $J$. natl Cancer Inst. 48, 1217-1224.

Nicholson, R.I. \& Golder, M.P. (1975) The effect of synthetic antioestrogens on the growth and biochemistry of rat mammary tumours. Eur. J. Cancer 11, 571-579.

Nicholson, R.I. \& Maynard, P.V. (1979) Anti-tumour activity of ICI 118630 , a new potent luteinizing hormone-releasing hormone agonist. $\mathrm{Br} . \mathrm{J}$. Cancer 39, 268-273.

Nicholson, R.I., Davies, P. \& Griffiths, K. (1978) Tamoxifen binding in mammary tumours in relation to response. In Reviews in Endocrine-Related Cancer, Suppl. pp. 306-321. ICI Ltd, Macclesfield. 
Nicholson, R.I., Walker, K.J. \& Maynard, P.V. (1980) Anti-tumour potential of a new luteinizing hormone releasing hormone analogue, ICI 118630 . In Breast Cancer: Experimental and Clinical Aspects, pp. 295-299. Eds H. T. Mourisden \& T. Palshof. Pergamon Press, Oxford.

Oshima, H., Nankin, H.R., Fan, D.F, Troen, P., Yanaihara, T., Niizato, N., Yoshida, K-I. \& Ochiai, K-I. (1975) Delay in sexual maturation of rats caused by synthetic LH-releasing hormone: enhancement of steroid $\triangle-5 \alpha$-hydrogenase in testes. Biol. Reprod. 12 , 491-497.

Pearson, O.H., Llerena, O., Llerena, L., Molina, A. \& Butler, T. (1969) Prolactin-dependent rat mammary cancer. A model for man? Trans. Assoc. Am. Physicians 82, 225-238.

Pearson, O.H., Molina, A., Butler, T.P., Llerena, L. \& Nasr, H. (1972) Estrogens and prolactin in mammary cancer. In Estrogen Target Tissues and Neoplasia, pp. 287-305. Ed. T. L. Dao. Univeristy of Chicago Press.

Pelletier, G., Cusan, L., Auclair, C., Kelly, P.A., Désy, L. \& Labrie, F. (1978) Inhibition of spermatogenesis in the rat by treatment with [D-Ala ${ }^{6}$, des Gly- $\mathrm{NH}_{2}{ }^{10}$ ] LHRH ethylamide. Endocrinology 103, 641-643.

Reeves, J.J., Seguin, C., Lefebvre, A., Kelly, P.A. \& Labrie, F. (1980) Similar luteinizing hormonereleasing hormone binding sites in rat anterior pituitary and ovary. Proc. natn. Acad. Sci., U.S.A. 77, 5567-5571.

Rippel, R.A. \& Johnson, E.S. (1976) Inhibition of HCG-induced ovarian and uterine weight augmen- tation in the immature rat by analogs of $\mathrm{Gn}-\mathrm{RH}$. Proc. Soc. exp. Biol. Med. 152, 432-436.

Rivier, C., Rivier, J. \& Vale, W. (1979) Chronic effects of [D-Trp ${ }^{6}$-Pro ${ }^{9}-\mathrm{NEt}$ ] luteinizing hormone-releasing factor on reproductive processes in the female rat. Endocrinology 103, 2299-2305.

Sandow, J., Von Rechenberg, W., Jerzabek, G. \& Stoll, W. (1978) Pituitary gonadotrophin-inhibition by a highly active analog of luteinizing hormone-releasing hormone. Fert. Steril. 30, 205-209.

Sharpe, R.M. (1976) HCG-induced decrease in availability of rat testes receptors. Nature, Lond. 264, 644-646.

Sterental, A., Dominguez, J.M., Weissman, C. \& Pearson, O.H. (1963) Pituitary role in the estrogen dependency of experimental mammary cancer. Cancer Res. 23, 481-484.

Sundaram, K., Cao, Y-Q., Wang, N-G, Bardin, C.W., Rivier, J. \& Vale, W. (1981) Inhibition of the action of sex steroids by gonadotrophin-releasing hormone (GnRH) agonists: a new biological effect. Life Sci. 28, 83-88.

Tcholakian, R.K., de la Cruz, A., Chowdhury, M., Steinberger, A., Coy, D.H. \& Schally, A.V. (1978) Unusual anti-reproductive properties of the analog [D - Leu ${ }^{6}$, des - Gly - NH ${ }^{10}$ ] - luteinizing hormonereleasing hormone ethylamide in male rats. Fert. Steril. 30, 600-603.

Vale, W., Rivier, C., Rivier, J. \& Brown, M. (1977) Diverse roles of hypothalamic regulatory peptides. In Medicinal Chemistry, Vol. 5, pp. 25-62. Ed. J. Mathieu. Elsevier Scientific, Amsterdam. 